\title{
The effect of astaxanthin and $\beta$-carotene inclusion in diets for growth, reproduction and pigmentation of the peppermint shrimp Lysmata wurdemanni
}

\author{
Lorenzo Díaz-Jiménez ${ }^{1}$, Martha Patricia Hernández-Vergara ${ }^{1}$ \\ Carlos Iván Pérez-Rostro ${ }^{1} \&$ Luis Alfredo Ortega-Clemente ${ }^{1}$ \\ ${ }^{1}$ Boca del Río Technology Institute, Posgraduate Study and Investigation \\ Division Veracruz, Boca del Río, Veracruz, México \\ Corresponding author: Martha Patricia Hernández-Vergara (mphv1@yahoo.com.mx)
}

\begin{abstract}
The effect of the incorporation of three different concentrations $(0.5,1$ and $1.5 \%)$ of either astaxanthin (A) or $\beta$-carotene (B) was evaluated during the feeding of peppermint shrimp Lysmata wurdemanni post-larvae with six isonitrogenous $(34 \%)$ and isolipidic $(8 \%)$ diets. Six treatments: $\mathrm{A}(0.5), \mathrm{A}(1), \mathrm{A}(1.5), \mathrm{B}(0.5)$, $\mathrm{B}(1)$ and $\mathrm{B}(1.5)$, and a control group were evaluate with three replicates and five post-larvae (initial weight 0.03 $\pm 0.007 \mathrm{~g}$ ) per replicate. After 105 days of culture, the survival, weight gain, number of molts and gravid female, protein, energy content of fertile eggs and the carotenoid content in cephalothorax and abdomen of the shrimp per treatment group were recorded. The survival of the shrimp was similar in both astaxanthin and $\beta$-carotene treatment groups; however, in both treatment groups was significantly higher than the control group, while growth was similar in all treatments. The greatest quantity of molts and ovigerous female were observed in the $\mathrm{A}(1)$ and $\mathrm{A}(1.5)$ groups; besides, the eggs of the females in $\mathrm{A}(1)$ that had the highest protein and energy content. A negative correlation $\left(\mathrm{R}^{2}=-0.93\right)$ was recorded between increasing dietary astaxanthin and body accumulation; in contrast, an increase in dietary $\beta$-carotene was positively correlated $\left(\mathrm{R}^{2}=0.80\right)$ with body accumulation. The results indicate that both sources of carotenoids promote survival and growth and improve egg quality and pigmentation.
\end{abstract}

Keywords: Lysmata wurdemanni; ornamental shrimp; carotenoids; egg quality

\section{INTRODUCTION}

The interest in the production of ornamental marine invertebrates has increased in recent years due to their growing demand and price by the marine aquarium market (Leal et al., 2015). The crustaceans of the genus Lysmata are species of particular interest to the marine aquarium market (Wabnitz et al., 2003; Bruckner, 2005), and there have been several efforts to develop biotechnologies for the cultivation of species of interest to meet worldwide demand. Many studies have been implemented to understand the biological aspects, environmental requirements and the cultivation of the species under controlled conditions, with a particular focus on the species Lysmata wudemanni (Zhang \& Lin, 2006; Zhang et al., 2009). Unfortunately there exist some bottlenecks that need to be resolved before managing the mass production of reef crustaceans, such as the complexity of their larval development, the de- crease in body pigmentation due to culture conditions and the diets implemented during their maintenance which can reduce their market price. For this reason, different strategies have been attempted to improve and maintain body pigmentation, including the incorporation of pigments into the diet, and the variation of the background color, such as the intensity and type of illumination in the habitat (Regunathan \& Wesley, 2006; Yuangsoi et al., 2011; Calvo \& Roldán, 2016). It has been demonstrated that the addition of carotenoids in the diets for penaeid shrimps can maintain or improve their pigmentation (Supamattaya et al., 2005; Ju et al., 2011; Wade et al., 2015a), thus it is necessary to develop protocols that allow each species of interest to obtain the optimum pigment concentrations. In addition, to improve the pigmentation, the presence of carotenoids in the diets of crustaceans increase their survival and reproduction (Calado, 2009), due to their antioxidant activity and their contribution to the neutra-

Corresponding editor: Mauricio Laterça 
lization of free radicals in the cells of the organism (Torrisen \& Christiansen, 1995; Meyers \& Latscha, 1997; Bjerkeng, 2008).

Due to the physiological role of carotenoids in the development of aquatic species and the lack of information about their effect on marine ornamental shrimp, the objective of the present study was to determine the effect of the inclusion of astaxanthin and $\beta$-carotene on variables of growth, reproduction and pigmentation of the peppermint shrimp $L$. wurdemanni. Also, this study contributes to the development of protocols of cultivation and maintenance of the species under a sustainable aquaculture scheme.

\section{MATERIALS AND METHODS}

\section{Peppermint shrimp post-larvae}

In this study were used 105 post-larvae (PL) peppermint shrimp Lysmata wurdemanni of the same age (after completing their metamorphosis between day 45 and 47), with an initial weight of $0.03 \pm 0.007 \mathrm{~g}$ and length $1.15 \pm 0.12 \mathrm{~cm}$. These were derived from the Itboca reproduction batch of three spawning females (3 to $4 \mathrm{~cm}$ in total length). The larvae were cultured in cylindric spherical tanks (Calado et al., 2008) installed in a recirculation system with marine water at a salinity of $34 \pm 2 \mathrm{~g} \mathrm{~L}^{-1}$ and a temperature of $27 \pm 1.5^{\circ} \mathrm{C}$, following the protocol established by Díaz-Jiménez et al. (2017).

\section{Experimental design and diets}

Five treatments (diets) with different carotenoid source and inclusion level with three replicates and five postlarvae per replicate were used. The number of PLs per replicate was established based on the number PLs obtained during two days since larval development is asynchronous, and although the larvae had the same hatching date, the metamorphosis varied by between 38 and 67 days (Zhang et al., 1998).

Six isonitrogenous (34\%) and isolipidic (8\%) diets were used in the study and a control group without dietary pigment (TC). Each diet included either astaxanthin (A) or $\beta$-carotene (B) in the following concentratios: $0.5,1$, and $1.5 \%$. Therefore, the treatment groups were denoted as follows: $\mathrm{A}(0.5), \mathrm{A}(1.0), \mathrm{A}(1.5)$, $\mathrm{B}(0.5), \mathrm{B}(1.0), \mathrm{B}(1.5)$ (Table 1).

The basal diet used for the study was developed under prior laboratory evaluations during the maintenance, growth and reproduction of the peppermint shrimp L. wurdemanni.

The diets were elaborated according to the methodology described by Hernández-Vergara et al. (2003) and Cervantes-Santiago et al. (2010). Before
Table 1. Basal diet formula, and proximate content (means $\pm \mathrm{SD}$ ).

\begin{tabular}{lc}
\hline Ingredients & $\mathrm{g} \mathrm{kg}^{-1}$ \\
\hline Fish meal & 244 \\
Shrimp meal & 93 \\
Spirulina & 105 \\
Wheat meal & 407 \\
Fish oil & 2 \\
Safflower oil & 23 \\
Corn starch & 35 \\
Mineral mixture & 15 \\
Vitamin premixture & 15 \\
Carboxymethyl C & 40 \\
Garlic extract & 5 \\
Soy lecithin & 5 \\
DHA (krill) & 5 \\
aPigment $(\%)$ & $0,5,10$ and 15 \\
\hline \multicolumn{2}{c}{ Chemical and proximate composition } \\
\multicolumn{2}{c}{ of the basal diet $(\%)$} \\
\hline Protein & $33.6 \pm 0.3$ \\
Lipid & $8.4 \pm 0.2$ \\
Ash & $9.5 \pm 0.4$ \\
\hline
\end{tabular}

Fish meal: $64 \%$ protein, $10 \%$ lipid, $7 \%$ carbohydrate. Shrimp meal: $73 \%$ protein, $9 \%$ lipid, $4.4 \%$ carbohydrate. Spirulina: Arthrospira platensis (Spirulina spring ${ }^{\circledR}$, Naturales Roel, Edo México, México): $65 \%$ protein, $6 \%$ lipid, $16 \%$ carbohydrate. Wheatmeal: $11.7 \%$ protein, $1.3 \%$ lipid, $73 \%$ carbohydrate. Safflower oil (Oléico ${ }^{\circledR}$, Coral International, México). Premixture of vitamins and minerals: Vitamins, minerals, and lutein, Kirkland, Vitae laboratories, Jalisco, México. ${ }^{\text {aPigment: 0, 5, } 10}$ and $15 \mathrm{~g} \mathrm{~kg}^{-1}$ of the astaxanthin source (A) or $\beta$-carotene (B). A: astaxanthin (Natural), Genchem biotechnology Co., LTD, Taiwan, China. B: beta-carotene (15 MG). General Nutrition Center, Pittsburgh, Pennsylvania, USA.

use, the diets were ground and sieved to obtain a particular size of between 500 and $1,000 \mu$. The protein and energy $\left(\mathrm{kcal} \mathrm{kg}^{-1}\right)$ content of the diets were determined with an elemental analyzer Flash 2000 (Thermo Scientific ${ }^{\circledR}$, USA). A conversion factor of 5.8 was used to determine the protein content, based on the recommendations of Gnaiger \& Bitterlich (1984) for samples of marine origin. The lipid content was determined through the Soxhlet method, by triplicates, based on the techniques of the AOAC (2000) (Table 1).

\section{Experimental system}

The experiment was performed using a recirculation system with 21 experimental square units of PCV $(20 \times 20 \times 15 \mathrm{~cm})$ each individually supplied with water. The units were placed inside a fiberglass container of $1 \times 2 \mathrm{~m}$ and a $15 \mathrm{~cm}$ column of water. The system depended on biological, mechanical filtration (synthetic fibers, silica sand and biospheres) and a skimmer type deproteinizer. 


\section{Operation and maintenance}

During the 105 days of study, the PLs were fed twice per day (9:00 and 18:00 h) with a ration equivalent to $5 \%$ of their total biomass in each feeding. Before the first feeding, the experimental units were siphoned to eliminate any unconsumed feed and feces. The biometric measurements were every 15 days, where the weight and total length (from the telson to the tip of the rostrum) of the shrimp were determined with a digital balance (Ohaus Scout Pro, China) and a ruler graded in millimeters, respectively. The food was adjusted relative to the increase in biomass.

The temperature $\left({ }^{\circ} \mathrm{C}\right)$, dissolved oxygen $\left(\mathrm{mg} \mathrm{L}^{-1}\right)$, salinity and $\mathrm{pH}$ were recorded every day using a multiparametric probe (YSI 556-MPSMulri-Prove, YSI, Yellow springs, $\mathrm{OH}$ ). Ammonium (NH3), nitrite (NO2) and nitrate (NO3), phosphate (PO4), and water hardness $(\mathrm{KH})$ were measured every 15 days using colorimetric tests (Hagen, Nutrafin $\AA$, Canada).

\section{Response variables}

At the end of the experiment, the effect of the diets was evaluated as functions of survival, weight gain $(\mathrm{WG}=$ $\left.\left(\mathrm{F}_{\mathrm{w}}-\mathrm{I}_{\mathrm{w}} / \mathrm{I}_{\mathrm{w}}\right) \times 100\right)$, daily weight gain $(\mathrm{DWG}=\Sigma \mathrm{TWG}$ week)/T) and specific growth rate $\left(\mathrm{SGR}=\left[\left(\ln \mathrm{F}_{\mathrm{w}}-\ln \right.\right.\right.$ $\left.\left.\mathrm{I}_{\mathrm{w}}\right) / T\right] \times 100$, where $\mathrm{F}_{\mathrm{w}}=$ final weight $(\mathrm{g}), \mathrm{I}_{\mathrm{w}}=$ initial weight (g), $\Sigma \mathrm{TWG}=$ total weight gained $(\mathrm{g}), \mathrm{T}=$ time in days, and $\ln =$ natural logarithm. In addition, the number of molts and ovigerous females per treatment was recorded through direct visual examination in each culture unit and without extracting the shrimp. The molt data was analyzed as "percentage of molts": Means percentage of registered molts in 12 days in relation to the total shrimp per treatment. The ovigerous females were analyzed as "percentage of ovigerous female": means the percentage of ovigerous female recorded (per week of culture) concerning the total shrimp per treatment.

The effect of the diets on the quality of the peppermint shrimp egg was evaluated through proximate chemical analysis, with the protein content and stored energy of fertile eggs with an average life of $12 \mathrm{~h}$ considered as parameters of quality.

During the last week of culture, three ovigerous females were extracted from each treatment, and before the extraction of the ovigerous mass, they were anesthetized with a solution of clove oil $\left(180 \mathrm{mg} \mathrm{L}^{-1}\right)$ diluted in $1 \mathrm{~L}$ of water from the culture system. The ovigerous mass was separated from the pleopods with tweezers for dissection, and they were placed on a plastic sheet with 30 cups of $2 \mathrm{~mL}$ capacity. The shrimps were returned to the treatments. The fresh sample was transported to the Laboratory of Aquacul- ture Biotechnology of ITBoca, and subsequently, the excess water was eliminated with absorbent paper, and a sample of between 2 and $6 \mathrm{mg}$ was weighed with a microbalance (Mettler Toledo, XP6) with an accuracy of $0.001 \mathrm{mg}$. The protein content, $\mathrm{C}, \mathrm{N}$ and energy (kcal $100 \mathrm{~g}^{-1}$ ) was determined in an elemental analyzer (Flash 2000 Thermo Scientific ${ }^{\circledR}$, USA).

Spectrophotometry determined the total corporal carotenoids content (cephalothorax and abdomen) in the shrimps according to the description by Yanar et al. (2004). At the end of the study, three shrimps from each treatment group were dissected, separating the cephalothorax and abdomen, which were each placed in a 12 $\mathrm{mL}$ glass tube, and $10 \mathrm{~mL}$ of anhydrous acetone was added to each tube. Subsequently, the sample was ground with a glass rod until a homogenous sample was obtained. The tubes were covered in aluminum paper and refrigerated at $4^{\circ} \mathrm{C}$ for $72 \mathrm{~h}$ before their analysis. Following the refrigeration period, the samples were placed in a centrifuge (Hettich, Zentrifugen Universal $32 \mathrm{R})$ at $4,000 \mathrm{rpm}$ for $7 \mathrm{~min}$ at $4^{\circ} \mathrm{C}$. The supernatant was placed in vials of $10 \mathrm{~mL}$ in preparation for the subsequent examination on a spectrophotometer (Genesys 10S, Thermo Scientific) used visible UV at an absorbance of $450 \mathrm{~nm}$.

\section{Statistical analysis}

The data were tested for normality and homogeneity of variances using Shapiro-Wilk and Levens tests, respectively (Sokal \& Rholf, 1995). Subsequently, the data were subject to a one way analysis of variance (ANOVA) followed by a posteriori Tukey method. A linear regression analysis was applied to define the relationship between the total carotenoid content in the body of the peppermint shrimp and the content of carotenoid in each of the diets. The analysis was carried out at the $95 \%$ significance level using the software Statistica v.10.0 (Dell, Round Rock, TX, USA).

\section{RESULTS}

During the experiment, the parameters of water quality were maintained constant and within the reported range for the growth of the genus Lysmata (Zhang et al., 2007; Calado et al., 2009; Johnson \& Rhyne, 2015), and was, therefore, assumed not to affect the results. The mean values of the parameters were: ammonium $=$ $0.04 \pm 0.02 \mathrm{mg} \mathrm{L}^{-1}$, nitrite $=0.13 \pm 0.30 \mathrm{mg} \mathrm{L}^{-1}$, nitrate $=11 \pm 7 \mathrm{mg} \mathrm{L}^{-1}$, phosphate $=4 \pm 1.9 \mathrm{mg} \mathrm{L}^{-1}$, water hardness $=200 \pm 38 \mathrm{mg} \mathrm{L}^{-1}$, calcium $=>400 \mathrm{mg} \mathrm{L}^{-1}$, $\mathrm{pH}=8.0 \pm 0.2$, salinity $=33 \pm 2$, temperature $=28 \pm$ $0.8^{\circ} \mathrm{C}$ and dissolved oxygen $=5.0 \pm 0.2 \mathrm{mg} \mathrm{L}^{-1}$. 
The survival of the shrimp during the first 90 days of culture was $100 \%$ for all the treatment groups; however, during the last two weeks of the study, mortality was recorded between 2 and $9 \%$ in treatment groups containing dietary $\beta$-carotene and in the control group. At the end of the study, survival was significantly higher in the treatments A0.5, A1.0 and A1.5 compared to control (Table 2).

The WG and SGR of the peppermint shrimp Lysmata wurdemanni were similar among the treatment groups (Table 2). The number of molts recorded during the study was similar among treatment groups. While the percentage of ovigerous females of treatment $A(1.0)$ was significantly higher than reported in the treatment $\mathrm{A}(0.5), \mathrm{B}(0.5), \mathrm{B}(1.0), \mathrm{B}(1.5)$ and $\mathrm{TC}$ (Table $3)$.

The source and percentage of carotenoids in the diet affected the chemical and proximate composition of the eggs. The protein content of the eggs of females fed diet $\mathrm{A}(1.0)$ was significantly higher $(P<0.05)$ than the result obtained from females fed diet B(1.0). Similarly, the higher energy content present in eggs of females fed $\operatorname{diet} \mathrm{A}(1.0)$ was significantly higher $(P<0.05)$ than the energy content of eggs produced by females fed the control diet. The carbon content of the eggs of the treatment $\mathrm{A}(1.0), \mathrm{B}(0.5), \mathrm{B}(1.5)$ and $\mathrm{TC}$ was between 7 and $10 \%$ higher than the carbon content of eggs recorded in treatment group $\mathrm{B}(1.0)$. In respect to the accumulation of carotenoids in the body of the shrimp, a highly significant $(P<0.01)$ correlation was recorded between the increase in the level of carotenoids included in the diet and the accumulation of total carotenoids content in the body. The shrimp fed the diets supplemented with $1.5 \%$ astaxanthin, accumulated a lower quantity of the pigment in the abdomen $\left(\mathrm{R}^{2}=\right.$ $-0.93)$ and the cephalothorax $\left(\mathrm{R}^{2}=-0.91\right)$ in compareson with the shrimp fed a higher concentration of $\beta$ carotene, which accumulated the highest concentration of carotenoid in the abdomen $\left(\mathrm{R}^{2}=0.80\right)$ (Fig. 1).

The total carotenoids content in the abdomen and cephalothorax of the shrimp of treatment $\mathrm{A}(0.5)(\approx 215$ $\mathrm{mg} \mathrm{kg}{ }^{-1}$ ) was similar to the mean of carotenoid in the abdomen of shrimp of treatment group B(1.5) $\approx 231 \mathrm{mg}$ $\mathrm{kg}^{-1}$ ), and both values were significantly higher than those recorded in treatment $\mathrm{A}(1.0), \mathrm{A}(1.5), \mathrm{B}(0.5)$ and TC (Fig. 2).

Table 2. Means \pm SD of evaluated response variables. Different subscript letters in a same column indicate significant differences $(P<0.05)$. S: survival, Fw: final weight, WG: weight gain, DWG: daily weight gain, and SGR: specific growth rate.

\begin{tabular}{lccccc}
\hline Treatment & $\begin{array}{c}\text { S } \\
(\%)\end{array}$ & $\begin{array}{c}\text { Fw } \\
(\mathrm{g})\end{array}$ & $\begin{array}{c}\text { WG } \\
(\%)\end{array}$ & $\begin{array}{c}\text { DWG } \\
\left(\mathrm{mg} \mathrm{d}^{-1}\right)\end{array}$ & $\begin{array}{c}\text { SGR } \\
\left(\% \mathrm{~d}^{-1}\right)\end{array}$ \\
\hline $\mathrm{A}(0.5)$ & $100^{\mathrm{a}}$ & $0.28 \pm 0.01$ & $717 \pm 28$ & $2.7 \pm 0.05$ & $1.00 \pm 0.16$ \\
$\mathrm{~A}(1.0)$ & $100^{\mathrm{a}}$ & $0.27 \pm 0.03$ & $461 \pm 16$ & $2.4 \pm 0.41$ & $0.82 \pm 0.14$ \\
$\mathrm{~A}(1.5)$ & $100^{\mathrm{a}}$ & $0.28 \pm 0.06$ & $554 \pm 15$ & $2.7 \pm 0.65$ & $0.90 \pm 0.12$ \\
$\mathrm{~B}(0.5)$ & $98 \pm 4^{\mathrm{ab}}$ & $0.28 \pm 0.03$ & $660 \pm 14$ & $2.7 \pm 0.35$ & $0.97 \pm 0.09$ \\
$\mathrm{~B}(1.0)$ & $98 \pm 4^{\mathrm{ab}}$ & $0.25 \pm 0.02$ & $575 \pm 28$ & $2.4 \pm 0.36$ & $0.89 \pm 0.20$ \\
$\mathrm{~B}(1.5)$ & $96 \pm 4^{\mathrm{ab}}$ & $0.27 \pm 0.04$ & $610 \pm 88$ & $2.6 \pm 0.41$ & $0.94 \pm 0.06$ \\
$\mathrm{TC}$ & $91 \pm 4^{\mathrm{b}}$ & $0.29 \pm 0.03$ & $834 \pm 43$ & $2.8 \pm 0.42$ & $1.05 \pm 0.21$ \\
$P$ & 0.01 & 0.93 & 0.64 & 0.85 & 0.59 \\
\hline
\end{tabular}

Table 3. Means \pm SD of the evaluated reproductive variables. Values with different subscript letters in the same column indicate significant differences $(P<0.05)$. N: nitrogen, $\mathrm{C}$ : carbon.

\begin{tabular}{|c|c|c|c|c|c|c|}
\hline \multirow[b]{2}{*}{$\begin{array}{l}\text { Treatment } \\
\text { female }\end{array}$} & \multirow[b]{2}{*}{$\begin{array}{l}\text { Percentage } \\
\text { of molts }\end{array}$} & \multirow[b]{2}{*}{$\begin{array}{c}\text { Percentage of } \\
\text { ovigerous }\end{array}$} & \multicolumn{4}{|c|}{ Proximate chemical composition of the eggs } \\
\hline & & & $\mathrm{N}(\%)$ & $\mathrm{C}(\%)$ & Protein $(\%)$ & $\begin{array}{c}\text { Energy } \\
\left(\mathrm{kcal} 100 \mathrm{~g}^{-1}\right)\end{array}$ \\
\hline $\mathrm{A}(0.5)$ & $38 \pm 20$ & $13 \pm 01^{\mathrm{cb}}$ & $7.3 \pm 0.3^{\mathrm{ab}}$ & $29.9 \pm 1.4^{\mathrm{ab}}$ & $42.3 \pm 1.7^{\mathrm{ab}}$ & $342 \pm 16^{\mathrm{ab}}$ \\
\hline $\mathrm{A}(1.0)$ & $41 \pm 15$ & $33 \pm 01^{\mathrm{a}}$ & $8.4 \pm 1.4^{\mathrm{a}}$ & $35.1 \pm 5.4^{\mathrm{a}}$ & $48.9 \pm 8.0^{\mathrm{a}}$ & $397 \pm 51^{\mathrm{a}}$ \\
\hline $\mathrm{A}(1.5)$ & $41 \pm 11$ & $24 \pm 41^{\mathrm{ba}}$ & $7.6 \pm 1.0^{\mathrm{ab}}$ & $30.6 \pm 4.2^{\mathrm{ab}}$ & $44.0 \pm 6.0^{\mathrm{ab}}$ & $320 \pm 51^{\mathrm{ab}}$ \\
\hline $\mathrm{B}(0.5)$ & $31 \pm 16$ & $13 \pm 11^{\mathrm{cb}}$ & $7.9 \pm 0.6^{\mathrm{ab}}$ & $32.5 \pm 2.1^{\mathrm{a}}$ & $46.3 \pm 3.4^{\mathrm{ab}}$ & $337 \pm 82^{\mathrm{ab}}$ \\
\hline $\mathrm{B}(1.0)$ & $31 \pm 80$ & $18 \pm 40^{\mathrm{cb}}$ & $6.5 \pm 0.4^{\mathrm{b}}$ & $25.5 \pm 0.7^{b}$ & $37.7 \pm 2.3^{b}$ & $285 \pm 49^{\mathrm{ab}}$ \\
\hline $\mathrm{B}(1.5)$ & $43 \pm 40$ & $4 \pm 40^{\mathrm{c}}$ & $7.9 \pm 0.2^{\mathrm{ab}}$ & $32.1 \pm 0.2^{\mathrm{a}}$ & $45.7 \pm 1.4^{\mathrm{ab}}$ & $342 \pm 45^{\mathrm{ab}}$ \\
\hline $\mathrm{TC}$ & $29 \pm 80$ & $20 \pm 70^{\mathrm{cb}}$ & $7.9 \pm 0.4^{\mathrm{ab}}$ & $33.2 \pm 1.1^{\mathrm{a}}$ & $46.0 \pm 2.6^{\mathrm{ab}}$ & $276 \pm 13^{\mathrm{b}}$ \\
\hline$P$ & 0.3 & $<0.01$ & 0.02 & $<0.01$ & 0.03 & 0.04 \\
\hline
\end{tabular}



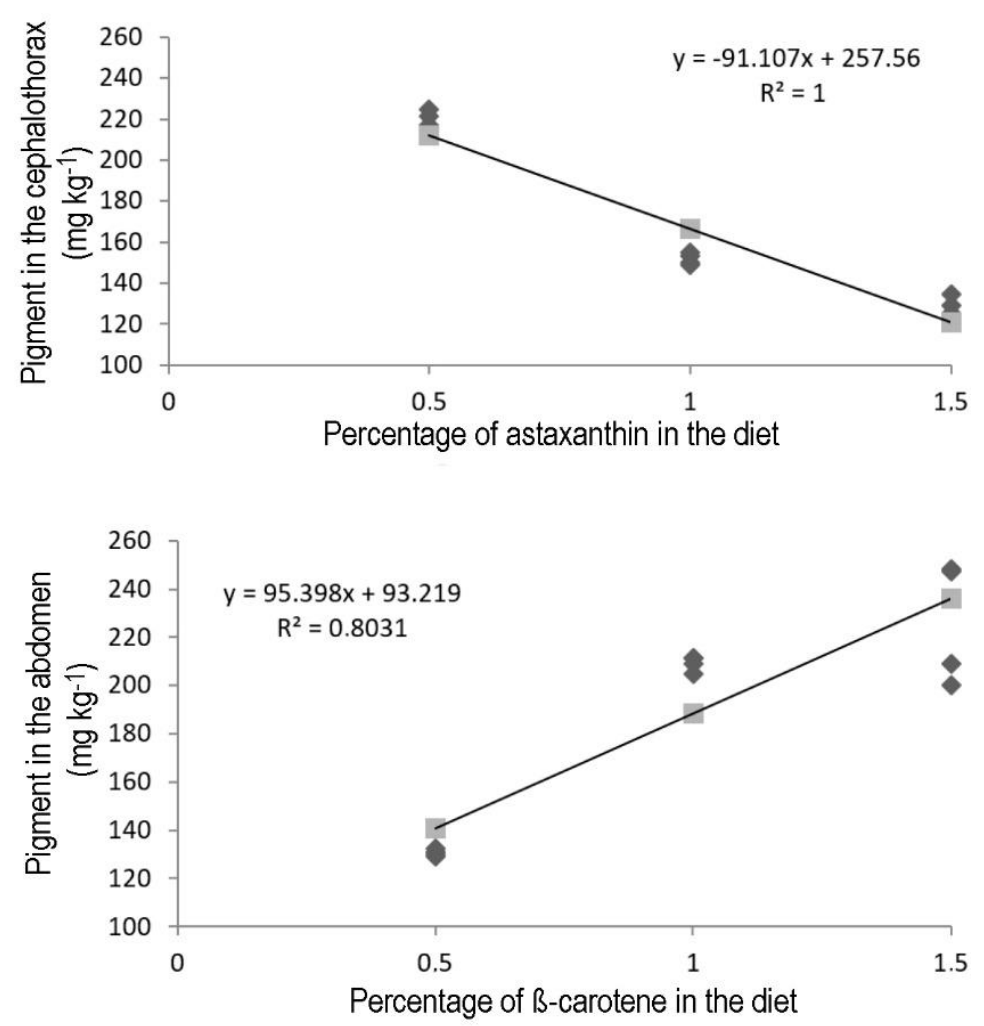

Figure 1. Correlation between the level of carotenoids included in the diet and the accumulation of total pigments content in the body.

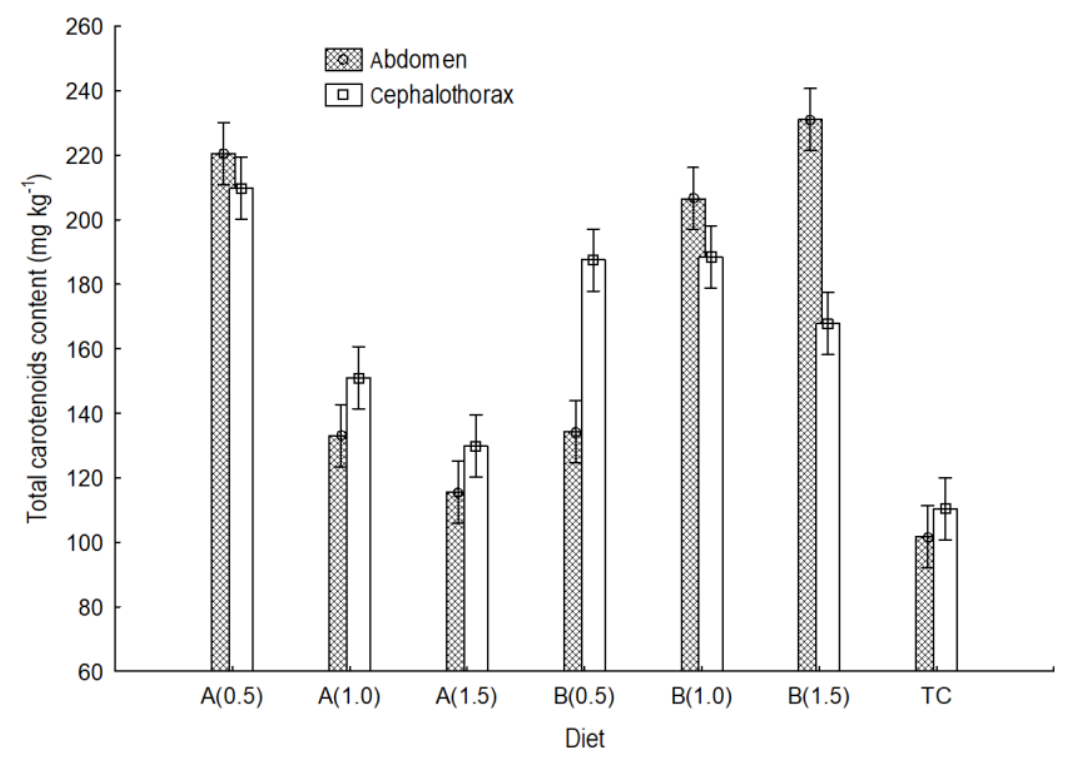

Figure 2. Variation in the content of total carotenoids content in the abdomen and cephalothorax of the peppermint shrimp Lysmata wurdemanni, concerning the source of the pigment (A: astaxanthin, B: $\beta$-carotene) and the content of the pigment in the diet (inclusion percentage $=0.5,1.0$, and 1.5).

\section{DISCUSSION}

The present study is the first to evaluate the effect of two sources of carotenoids on the growth, proximate composition and energy content of Lysmata wurdemanni eggs; therefore, these results are an important contribution to the knowledge of this species. The results demonstrate that independent of both the 
source and the dietary content of carotenoids, at least the presence of these nutrients improve survival compared to the control group. This finding is believed to be due to the antioxidant properties of the carotenoids that eliminate free radicals derived from oxidative stress and prevent the peroxidation of dietary PUFAs and animal tissues, which positively impacts on the species' health state and survival (Chien et al., 2003; Wade et al., 2015b). Niu et al. (2009) reported that the inclusion of between 100 and $400 \mathrm{mg} \mathrm{kg}^{-1}$ astaxanthin in the diet of white shrimp Penaeus vannamei postlarvae (for 30 days) improved survival (70-78\%) compared to diets without carotene $(49 \%$ survival). Thus, it is recommended that carotenoids, like antioxidants, be incorporated into the diet, particularly astaxanthin that is 10 times more efficient than $\beta$-carotenes (Meyers \& Latscha, 1997). This lack in efficiency is due to how crustaceans metabolize $\beta$ carotene; astaxanthin esters are formed during the metabolism of the $\beta$-carotene, which are used as an energy source, unlike esters generated by the direct use of astaxanthin (Meyers \& Latscha, 1997). These metabolic differences may be responsible for the higher survival and egg quality observed in shrimp fed astaxanthin diets in comparison with shrimp fed the $\beta$ carotene diets.

In addition to the survival, Flores et al. (2007), Calado (2009) and Wade et al. (2015b) indicated that the presence of carotenoids in the diets of shrimp promote rapid growth. However, in the current study, a similar rate of growth was observed among treatments, independently of the dietary content, absence/presence, or source of the pigments. Thus, it is probable that the basal diet alone (excluding pigment) contained the nutritional components necessary for growth; for example, shrimp meal and Spirulina, may both contain pigments in sufficient proportions to meet the minimum nutritional requirements for the growth of this species. Similarly, Ju et al. (2011) reported that the white shrimp, Penaeus vannamei (=Litopenaeus vannamei), has a similar rate of growth among those fed without pigments, and those fed with astaxanthin extracted from the microalgae Haematococus pluvialis, or synthetic astaxanthin, indicative of the shrimp's capacity to use both sources, which is precisely what occurred in the present study with the two carotenoid sources.

In contrast, Wade et al. (2015a) found that the weight of juvenile black tiger shrimp Penaeus monodon was significantly greater when astaxanthin was provided in the diet in comparison with diets that did not include astaxanthin. The differences in how different crustacean species use different sources of carotenoids may be due to their food preferences and metabolic requirements, since carnivorous species such as $P$. monodon (Guillaume, 1997) have higher nutrient requirements compared to omnivorous species such as L. vannamei, freshwater prawn Macrobrachium rosenbergii or L. wurdemanni (Pascual et al., 2004; Rhyne \& Lin, 2004; Teshima et al., 2006). In accordance with this, it has been reported that crustaceans (especially omnivorous species) can modify their metabolic activity according to the availability or the quality of the feed, thus they can more efficiently make use of the nutrients in the diet, which is typically observed in response to the presence of dietary carotenoids (Harpaz et al., 1998; Calvo \& Roldán, 2016).

On the other hand, similar to lipids, the carotenoids play an essential role in the reproduction of crustaceans, primarily in the formation of gonads, the number of eggs produced and the hatch rate or total larvae produced (Wade et al., 2015b). In the present study, it was observed that the inclusion of $1 \%$ astaxanthin in the diet of peppermint shrimp promoted a more significant percentage of ovigerous females (33\% of the population), which was different from the diets supplemented with $\beta$-carotene (4 to $18 \%$ of the total shrimp) or the control group (20\%). This difference is a result of crustacean's greater ability to metabolize astaxanthin than $\beta$-carotene, and the metabolism of astaxanthin facilitates its storage in the hepatopancreas. Once accumulated, the carotenoids are utilized for the maturation of the gonads, since during secondary vitellogenesis they are transported by the hemolymph to the ovaries (Wouters et al., 2001; Wade et al., 2015 b), which also promotes pigmentation of the gonads (Kalinina et al., 2009). The occurrence of pigment deficiencies during the period of reproduction can increase the risk of pigment deficiency syndrome in crustaceans. Therefore, Regunathan \& Wesley (2006) evaluated the effect of the incorporation of Spirulina $\left(30 \mathrm{~g} \mathrm{~kg}^{-1}\right)$ in pieces of squid used as feed for the pink shrimp Farfantepenaeus indicus, with what improved the quality of spawns, in addition to increasing the number and viability of nauplii. A similar result was obtained in the present study, whereby the incorporation of $1 \%$ astaxanthin in the diet resulted in a higher concentration of protein and energy in the egg, in comparison with the control group. These results indicate that, although shrimp require $\leq 0.5 \%$ of carotenoids in the diet for growth, during the reproductive phase it is necessary to increase carotenoid consumption to improve the quality and viability of the spawn; this is important since oocytes depend directly on the nutrients transferred from the mother for their development (Racotta et al., 2003). 
The results of this study indicate an explicit interaction between the carotenoids and the protein and energy composition of the eggs in development, which is related to the function of the pigments as bioactive molecules and their conversion into retinoid and is implicated in cellular development (Liñán-Cabello et al., 2002). However, it is important to consider that as embryonic development takes place, the proximate composition of eggs can vary due to the allocation of energy during the development of the embryo until its hatching (García-Guerrero et al., 2003).

On the other hand, it was observed that the two carotenoid sources promoted the accumulation of pigments in L. wurdemanni; however, an increase in levels of astaxanthin $(>0.5 \%)$ generated a decrease in its concentration in shrimp tissue, which could be related to saturation during metabolism and consequent elimination by excretion. Although astaxanthin can be freely deposited, esterified and integrated into protein complexes (carotenoprotein) (Matsuno, 2001), the assimilation of this pigment may also have a limit, and when an excess exists it can be discarded along with feces without being metabolized. In contrast, an increase in the level of $\beta$-carotene in the diet can increase the accumulation of esters of astaxanthin in the tissue. The oxidisation that occurs at the positions 3, 3', $4,4^{\prime}$ of $\beta$-ionone rings of $\beta$-carotene (Meyers \& Latscha, 1997; Tapia-Salazar et al., 2008), allowing a gradual increase relative to the dietary concentration, unlike the diets that contain astaxanthin, which can be readily integrated into metabolic processes (Chien \& Jeng, 1992). Yamada et al. (1990) reported (after eight weeks of culture) that in kuruma shrimp Penaeus japonicus, an increase in dietary astaxanthin from 0 to $200 \mathrm{mg} \mathrm{kg}^{-1}$ improve the carotenoid content in the muscle from 14 to $40 \mathrm{mg} \mathrm{kg}^{-1}$. However, further increases in dietary astaxanthin, such as up to $400 \mathrm{mg}$ $\mathrm{kg}^{-1}$, has no continued effect on muscle carotene concentration, indicative a maximum limit, which is similar to the observations of the peppermint shrimp made in the present study, where the increase of pigment in the diet, does not improve its accumulation in the tissue. It was also found that the content of pigments in the peppermint shrimp, L. wurdemanni, is generally higher to that reported for other commercial crustaceans (Boonyaratpalin et al., 2001; Supamattaya et al., 2005); this may be due to the intense colorations that are characteristic of crustaceans of the reef, which is the source of their interest in the marine aquarium market. However, it is important to consider that the coloration can vary between individuals of the same species (up to $300 \%$ ) due to sex, age, sexual maturity or type of feed consumed (Meyers, 2000). NégreSadargues et al. (2000) observed that the juvenile deep- sea shrimp, Rimicaris exoculata, accumulates a larger quantity of carotene in the muscle $\left(325 \mu \mathrm{g} \mathrm{g}^{-1}\right)$ than that accumulated by adults $\left(79 \mu \mathrm{g} \mathrm{g}^{-1}\right)$. In this way, the higher concentration of carotenoid in the cephalothorax of the shrimp of treatment group $\mathrm{B}(0.5)$ was different compared to the content observed in the abdomen. It could be a result of the process of oogenesis observed in the majority of females of this group when compared to the shrimp of the other treatment groups, despite the initial postlarvae being of similar age. Other variables, such as the illumination conditions, background color, the season of the year and physiological state of the animals, can have an impact on the pigment content of the crustaceans, which should be considered during their cultivation (Yanar et al., 2004; Calvo \& Roldán, 2016). Under the studied conditions, it can be determined that the inclusion of $1 \%$ of astaxanthin in the pepper shrimp diet improved survival and growth, and promoted a higher quality of fertile eggs. However, the incorporation of other pigments such as $\beta b$-carotene can also be useful when used at levels above $1 \%$.

\section{ACKNOWLEDGMENTS}

The authors want to thank Tecnológico Nacional de México and ITBoca for the facilities and L.D.J doctorate studies, and the Consejo Nacional de Ciencia y Tecnología (CONACYT) for the scholarship No387491.

\section{REFERENCES}

Association of Official Analytical Chemists (AOAC). 2000. Official methods of analysis. Association of Official Analytical Chemists, Washington.

Boonyaratpalin, M., Thongrod, S., Supamattaya, K., Britton, G. \& Schlipalius, L.E. 2001. Effects of $\beta$ carotene source, Dunaliella salina, and astaxanthin on pigmentation, growth, survival, and health of Penaeus monodon. Aquaculture Research, 32: 182-190.

Bjerkeng, B. 2008. Carotenoids in aquaculture: fish and crustaceans. In: Britton, G., Liaaen-Jensen, S. \& Pfander, H. (Eds.). Carotenoids. Birkhäuser, Basel.

Bruckner, A.W. 2005. The importance of the marine ornamental reef fish trade in the wider Caribbean. Revista de Biología Tropical, 53: 127-137.

Calado, R. 2009. Marine ornamental shrimp: biology, aquaculture, and conservation. John Wiley \& Sons, New Jersey.

Calado, R., Pimentel, T., Vitorino, A., Dionísio, G. \& Dinis, M.T. 2008. Technical improvements of a rearing system for the culture of decapod crustacean 
larvae, with emphasis on marine ornamental species. Aquaculture, 285: 264-269.

Calado, R., Vitorino, A., Reis, A., Lopes da Silva, T. \& Dinis, M.T. 2009. Effect of different diets on larval production, quality, and fatty acid profile of the marine ornamental shrimp Lysmata amboinensis (De Man, 1888), using wild larvae as a standard. Aquaculture Nutrition, 15: 484-491.

Calvo, S.N. \& Roldán, L.M. 2016. Reflected-light influences the coloration of the peppermint shrimp Lysmata boggessi (Decapoda: Caridea). Journal of the World Aquaculture Society, 47: 701-711.

Cervantes-Santiago, E., Hernández-Vergara, M.P., PérezRostro, C.I. \& Olvera-Novoa, M.A. 2010. Proteinlipid ratio for the growth and survival of juvenile crayfish Procambarus acanthophorus (Hobbs, 1972) reared under controlled conditions. Aquaculture Research, 41: 62-71.

Chien, Y.H. \& Jeng, S.C. 1992. Pigmentation of kuruma prawn, Penaeus japonicus Bate, by various pigment sources and levels and feeding regimes. Aquaculture, 102: 333-346.

Chien, Y.H., Pan, C.H. \& Hunter, B. 2003. The resistance to physical stresses by Penaeus monodon juveniles fed diets supplemented with astaxanthin. Aquaculture, 216: 177-191.

Díaz-Jiménez, L., Pérez-Rostro, C.I., Hernández-Vergara, M.P. \& Pérez-Legaspi, I.A. 2017. Effect of diet and culture system on survival and development larval of banded shrimp Stenopus hispidus. Revista Mexicana de Biodiversidad, 88: 163-172.

Flores, M., Díaz, F., Medina, R., Re, A.D. \& Licea, A. 2007. Physiological, metabolic, and hematological responses in white shrimp Litopenaeus vannamei (Boone) juveniles fed diets supplemented with astaxanthin acclimated to low-salinity water. Aquaculture Research, 38: 740-747.

García-Guerrero, M., Racotta, I.S. \& Villarreal, H. 2003. Variation in lipid, protein, and carbohydrate content during the embryonic development of the crayfish Cherax quadricarinatus (Decapoda: Parastacidae). Journal of Crustacean Biology, 23: 1-6.

Guillaume, J. 1997. Protein and amino acids. In: D’Abramo, L.R., Conklin, D.E. \& Akiyama, D.M. (Eds.) Crustacean nutrition. Advances in world aquaculture vol. 6. World Aquaculture Society, Louisiana, pp. 26-50.

Gnaiger, E. \& Bitterlich, G. 1984. Proximate biochemical composition and caloric content calculated from elemental CHN analysis: a stoichiometric concept. Oecologia, 62: 289-298.

Harpaz, S., Rise, M., Arad, S.M. \& Gur, N. 1998. The effect of three carotenoid sources on growth and pigmentation of juvenile freshwater crayfish Cherax quadricarinatus. Aquaculture Nutrition, 4: 201-208.
Hernández-Vergara, M.P., Rouse, D.B., Olvera-Novoa, M.A. \& Davis, D.A. 2003. Effect of dietary lipid levels and source on growth and proximate composition of juvenile redclaw (Cherax quadricarinatus) reared under semi-intensive culture conditions. Aquaculture, 233: $107-115$.

Johnson, K.B. \& Rhyne, A.L. 2015. Ontogenetic shift of spectral sensitivity in the larval phototaxis of two sympatric caridean shrimp, Lysmata wurdemanni and L. boggessi (Decapoda: Lysmatidae). Marine Biology, 162: 1265-1273.

Ju, Z.Y., Deng, D.F. \& Dominy, W.G. 2011. Pigmentation of Pacific white shrimp, Litopenaeus vannamei, by dietary astaxanthin extracted from Haematococcus pluvialis. Journal of the World Aquaculture Society, 42: 633-644.

Kalinina, M.V., Zadorozhnyi, P.A. \& Vinnikova, N.A. 2009. Sexual cycle properties and changes in carotenoid levels in ovary of Japanese mitten crab Eriocheir japonica from rivers of Primorye. Russian Journal of Developmental Biology, 40: 176-182.

Leal, M.C., Vaz, M.C.M., Puga, J., Rocha, R.J.M., Brown, C., Rosa, R. \& Calado, R. 2015. Marine ornamental fish imports in the European Union: an economic perspective. Fish and Fisheries, 17: 459-468.

Liñán-Cabello, M.A., Paniagua-Michel J. \& Hopkins, P.M. 2002. Bioactive roles of carotenoids and retinoid in crustaceans. Aquaculture Nutrition, 8: 299-309.

Matsuno, T. 2001. Aquatic animal carotenoids. Fisheries Science, 67: 771-783.

Meyers, S.P. \& Latscha, T. 1997. Carotenoids. In: D’Abramo, L.R., Conklin, D.E. \& Akiyama, D.M. (Eds.). Crustacean nutrition. Advances in world aquaculture vol. 6. World Aquaculture Society, Louisiana, pp. 164-193.

Meyers, S.P. 2000. Papel del carotenoide astaxantina en nutrición de especies acuáticas. In: Civera-Cerecedo, R., Pérez-Estrada, C.J., Ricque-Marie, D. \& CruzSuárez, L.E. (Eds.). Avances en nutrición acuícola. Memorias del IV Simposium Internacional de Nutrición Acuícola, Baja California Sur, 473-491 pp.

Négre-Sadargues, G., Castillo, R. \& Segonzac, M. 2000. Carotenoid pigments and trophic behavior of deep-sea shrimps (Crustacea, Decapoda, Alvinocarididae) from a hydrothermal area of the Mid-Atlantic Ridge. Comparative Biochemistry and Physiology A, 127: 293-300.

Niu, J., Tian, L.X., Liu, Y.J., Yang, H.J., Ye, C.X., Gao, W. \& Mai, K.S. 2009. Effect of dietary astaxanthin on growth, survival, and stress tolerance of postlarval shrimp, Litopenaeus vannamei. Journal of the World Aquaculture Society, 40: 795-802.

Pascual, C., Zenteno, E., Cuzon, G., Sánchez, A., Gaxiola, G., Taboada, G. \& Rosas, C. 2004. Litopenaeus vannamei juveniles energetic balance and immuno- 
logical response to dietary protein. Aquaculture, 236: 431-450.

Racotta, I.S., Palacios, E. \& Ibarra, A.M. 2003. Shrimp larval quality in relation to bloodstock condition. Aquaculture, 227: 107-130.

Regunathan, C. \& Wesley, S.G. 2006. Pigment deficiency correction in shrimp bloodstock using Spirulina as a carotenoid source. Aquaculture Nutrition, 12: 425432.

Rhyne, A.L. \& Lin, J. 2004. Effects of different diets on larval development in a peppermint shrimp (Lysmata sp. (Risso)). Aquaculture Research, 35: 1179-1185.

Sokal, R.R. \& Rholf, F.J. 1995. Biometry: the principles and practice of statistics in biological research. Freeman and Company, New York.

Supamattaya, K., Kiriratnikom, S., Boonyaratpalin, M. \& Borowitzka, L. 2005. Effect of a Dunaliella extract on growth performance, health condition, immune response, and disease resistance in black tiger shrimp (Penaeus monodon). Aquaculture, 248: 207-216.

Tapia-Salazar, M., Ricque-Marie, D., Nieto-López, M. \& Cruz-Suárez, L.E. 2008. Uso de pigmentos de flor de cempasúchil (Tagetes erecta) como adictivos en alimentos para camarón L. vannamei. In: Cruz, S.L.E., Ricque, M.D., Tapia, S.M., Nieto, L.M.G., Villarreal, C.D.A., Lazo, J.P. \& Viana, M.T. (Eds.). Avances en nutrición acuícola. Memorias del IX Simposio Internacional de Nutrición Acuícola, Monterrey, 492$513 \mathrm{pp}$.

Teshima, S.I., Koshio, S., Ishikawa, M., Alam, M. \& Hernandez-Hernandez, L.H. 2006. Protein requirements of the freshwater prawn Macrobrachium rosenbergii evaluated by the factorial method. Journal of the World Aquaculture Society, 37: 145-153.

Torrissen, O.J. \& Christiansen, R. 1995. Requirements for carotenoids in fish diets. Journal of Applied Ichthyology, 11: 225-230.

Wabnitz, C., Taylor, M., Green, E. \& Razak, T. 2003. From ocean to aquarium (the global trade in marine ornamental species). UNEP World Conservation Monitoring Centre, Cambridge.

Received: 7 December 2018; Accepted: 20 May 2019
Wade, M.N., Gabaudan, J. \& Glencross, D.B. 2015b. A review of carotenoid utilization and function in crustacean aquaculture. Reviews in Aquaculture, 9: 141-156.

Wade, N.M., Cheers, S., Bourne, N., Irvin, S., Blyth, D. \& Glencross, B.D. 2015a. Dietary astaxanthin levels affect color, growth, carotenoid digestibility and the accumulation of specific carotenoid esters in the giant tiger shrimp, Penaeus monodon. Aquaculture Research, 48: 395-406.

Wouters, R., Lavens, P., Nieto, J. \& Sorgeloos, P. 2001. Penaeid shrimp broodstock nutrition: an updated review on research and development. Aquaculture, 202(1-2): 1-21.

Yamada, S., Tanaka, Y., Sameshima, M. \& Ito, Y. 1990. Pigmentation of prawn (Penaeus japonicus) with carotenoids: I. Effect of dietary astaxanthin, $\beta$ carotene, and canthaxanthin on pigmentation. Aquaculture, 87: 323-330.

Yanar, Y., Celik, M. \& Yanar, M. 2004. Seasonal changes in total carotenoid contents of wild marine shrimps (Penaeus semisulcatus and Metapenaeus monoceros) inhabiting the eastern Mediterranean. Food Chemistry, 88: 267-269.

Yuangsoi, B., Jintasataporn, O., Areechon, N. \& Tabthipwon, P. 2011. The pigmenting effect of different carotenoids on fancy carp (Cyprinus carpio). Aquaculture Nutrition, 17: 306-316.

Zhang, D. \& Lin, J. 2006. Effects of density and simulated recruitment and mortality on sex change in a protandric simultaneous hermaphroditic shrimp, Lysmata wurdemanni. Marine Biology, 150: 639-645.

Zhang, D., Lin, J. \& Creswell, R.L. 1998. Effects of food and temperature on survival and development in the peppermint shrimp Lysmata wurdemanni. Journal of the World Aquaculture Society, 29: 471-476.

Zhang, D., Lin, J. \& Huang, C. 2009. Relationship between olfactory sensor number and mating in a marine shrimp, Lysmata wurdemanni. Marine and Freshwater Behaviour and Physiology, 42: 265-273.

Zhang, D., Rhyne, A.L. \& Lin, J. 2007. Density-dependent effect on reproductive behavior of Lysmata amboinensis and L. boggessi (Decapoda: Caridea: Hippolytidae). Journal of the Marine Biological Association of the United Kingdom, 87: 517-522. 